NBER WORKING PAPER SERIES

\title{
SUPPLY AND DEMAND FOR DISCRIMINATION: \\ STRATEGIC REVELATION OF OWN CHARACTERISTICS IN A TRUST GAME
}

\author{
Anthony Heyes \\ John A. List \\ Working Paper 21953 \\ http://www.nber.org/papers/w21953
NATIONAL BUREAU OF ECONOMIC RESEARCH
1050 Massachusetts Avenue
Cambridge, MA 02138
February 2016

The authors are grateful to Daniel Mather and Florian Rundhammer for excellent research assistance, Kevin Ackaramongkolrotn for help with the software, and James Cox for advice and access to the Experimental Economics Center at Georgia State University. Thanks to Catherine Eckel and Ragan Petrie for providing relevant materials. The views expressed herein are those of the authors and do not necessarily reflect the views of the National Bureau of Economic Research.

NBER working papers are circulated for discussion and comment purposes. They have not been peerreviewed or been subject to the review by the NBER Board of Directors that accompanies official NBER publications.

(C) 2016 by Anthony Heyes and John A. List. All rights reserved. Short sections of text, not to exceed two paragraphs, may be quoted without explicit permission provided that full credit, including $\odot$ notice, is given to the source. 
Supply and Demand for Discrimination: Strategic Revelation of Own Characteristics in a Trust Game Anthony Heyes and John A. List NBER Working Paper No. 21953

February 2016

JEL No. C9,C91,D03,J71,J78

\title{
ABSTRACT
}

There is a large and diverse body of evidence that people condition their behavior on the characteristics of others. If type is visible then one agent seeing another with whom they are interacting, or observing some other close proxy for type, can affect outcomes. We explore the economics of revealing type in a simple laboratory experiment to learn about the underlying motivations for discrimination.

\author{
Anthony Heyes \\ Department of Economics \\ University of Ottawa \\ Faculty of Social Sciences \\ 120 University, Room 9029 \\ Ottawa CANADA K1N 6N5 \\ Anthony.Heyes@uottawa.ca \\ John A. List \\ Department of Economics \\ University of Chicago \\ 1126 East 59th \\ Chicago, IL 60637 \\ and NBER \\ jlist@uchicago.edu
}




\title{
Supply and Demand for Discrimination: Strategic Revelation of Own Characteristics in a Trust Game
}

\author{
By ANTHONY HEYES AND JOHN A. LIST*
}

\begin{abstract}
* Heyes: Department of Economics, University of Ottawa, 120 University, Ottawa, Canada K1N 6N5 (e-mail: aheyes@uottawa.ca). List: University of Chicago, 1126 East 59th Street, Chicago, Illinois 60637 (e-mail: jlist@uchicago.edu). The authors are grateful to Daniel Mather and Florian Rundhammer for excellent research assistance, Kevin Ackaramongkolrotn for help with the software, and James Cox for advice and access to the Experimental Economics Center at Georgia State University. Thanks to Catherine Eckel and Ragan Petrie for providing relevant materials.
\end{abstract}

There is a large and diverse body of evidence that people condition their behavior on the characteristics of others.

If type is visible then one agent seeing another with whom they are interacting, or observing some other close proxy for type, can affect outcomes. Goldin and Rouse (2000) showed that the adoption of 'blind' auditions - with a screen concealing each candidate's identity from the jury increased significantly the likelihood of a female being hired at five major American orchestras. Oreopoulos (2011) found that CV's sent in response to online job postings in Toronto were much more likely to elicit a response if they carried an English rather than Indian, Pakistani, Chinese or Greek name. In recent work on behavior in the 'sharing economy', Pope and Sydnor (2011) showed that loan listings on the Prosper.com peer-to-peer lending site were 25 to 35 percent less likely to receive funding if the borrower profile contained a black profile, while in their field experiment Edelman et al (2015) found that room requests on Airbnb from guests with distinctively African American names were 16\% less likely to be accepted than those from other requestors.

When the characteristic in question is a legally-protected one, as in these examples, we call prejudicial behavior towards a particular sub-group discrimination. But the conditioning of behavior on characteristics of others is more ubiquitous than our focus on race and gender would suggest. For example, Hammermesh and Biddle (2001) show that for labor market outcomes for both men and women are increasing in how good-looking they are rated as being in photographs (this behavior extends to even the charitable giving market; see Landry et al. (2006)). There is a broader literature on how people make inferences from faces. For example, Oosterhof and Todorov (2009) find that perceptions of the trustworthiness of an individual in a photo can vary 
systematically with facial expressions and characteristics. DeBruine (2002) found evidence that facial resemblance enhanced trust. Van Leeuwen et al (2014) find facial cues that predict propensity to anger. In Scharlemann et al (2001) experimental subjects are more likely to regard as co-operative a partner smiling in a photograph rather than of neutral expression.

The desire to discriminate may provide a rationale for wanting to know about the identity of someone with whom you are interacting. Much more generally, however, in strategic settings we tend to think that there are certain advantages to knowing the features of the other agent. We might be able to learn something from their appearance that allows us to turn negotiations and other interactions in our favor. Consistent with this line of thought, a clever study due to Eckel and Petrie (2011) demonstrate that players in a trust game often have a positive willingness to pay (WTP) to see a picture of their partner. That is, there is a perceived private value to the information that such a picture contains.

Our research question is in this spirit, but different in that we explore whether individuals perceive a benefit to revealing a picture of themselves to partners in a strategic interaction (a trust game). If they do, then it implies that players believe that they can use their own characteristics to shape the actions of others.

Our pilot results reported in this study should be viewed with care, as they are preliminary and based on small samples. Yet, we find a substantial (and significant) portion of players have a positive WTP for revelation of own characteristics. Indeed, the strategic revelation follows economic theory well-there is an associated demand curve that is downward sloping.

\section{Experimental Design and Procedures}

\section{A. Setup}

Our experiment features three treatments with a common design that is a perturbed version of Eckel and Petrie (2011). Every subject plays one standard trust game with each of two randomly assigned partners in the laboratory. Throughout the experiment a given subject has one fixed role, either first mover (trustor) or second mover (trustee).

In each trust game subjects are endowed with 10 experimental tokens regardless of their role. Each token is worth $\$ 1.50$ in all treatments. The trustor can send any number of tokens $s$ from her initial endowment to the trustee. The amount sent is tripled by the experimenters such that 
the trustee receives $3 s$ tokens. The trustee then decides how many tokens $r$ to return to the trustor (with the amount not to exceed 3s).

Our interest is in whether subjects perceive there to be value in revealing a picture of themselves to the subject with whom they are paired, and in what circumstances the revelation is not chosen.

Our three experimental cells vary in the extent to which subjects have the opportunity to reveal something about their own characteristics by showing a photograph of their face. In the first treatment cell (denoted C for control), neither trustors nor trustees have the option to reveal their identity and no photographs are shown to anyone. This is the standard baseline used in typical trust games.

In our second experimental cell (denoted T1 for treatment 1), we introduce the option to reveal one's own photograph for trustors only. Trustees face the same decisions as in C. After being instructed about the trust game but before making decisions, trustors can choose to reveal their own photograph for a positive price. In the third, and final, experimental cell (denoted T2 for treatment 2), trustees have the opportunity to reveal their own photograph for a price but trustors do not.

We use a modified version of the software applied by Eckel and Petrie (2011) to implement the trust games. Subjects make their decisions on two separate screens. The trustor uses a simple slider to choose $s$ and sees both the amount sent and the amount kept at all times. The trustee, on the other hand, sees two decision screens in the strategy method. This means that the second mover does not observe the actual amount received before making her decision about $r$. Instead, sliders are presented for all possible outcomes - that is all amounts $s$ the trustor could send - and both roles make decisions simultaneously.

In all treatments, subjects wait together in front of the laboratory and have enough time to observe the characteristics of others in the session before entering the lab privately. In T1 and T2, head and shoulders photographs with neutral expression are taken of all subjects with a digital camera. We take pictures of everyone, regardless of roles that are assigned randomly later. Depending on the treatment, either all trustors (T1) or all trustees (T2) face an additional decision before reaching the trust game stage. In this decision, subjects are asked if they are willing to pay some price to reveal their own photograph to their assigned partner. The prices 
used are 10 cents and $\$ 1$. The money they give up if they pay to reveal their picture is deducted from their final earnings. Note that all subjects in these treatment cells face both prices.

Payoffs are determined as follows. Subjects receive a \$10 show-up fee regardless of their decisions. Additionally, one of the two trust games is paid out. To decide which one is paid, a volunteer stands in front of the laboratory and blindly draws one ball from a bag containing four red and four white balls. If a red ball is drawn, then the first game is paid out; alternatively, if a white ball is drawn, then the second is paid out. Total payoffs are the sum of the show-up fee and the outcome in the chosen game, minus any price paid to reveal the picture.

\section{Data Overview}

Overall we observe decisions from 136 subjects in eight sessions, five of which are male only (N =92) and three are female only $(\mathrm{N}=44)$. All sessions were conducted the Experimental Economics Center (ExCEN) of Georgia State University. A typical session takes between 50 and 60 minutes and average realized payoffs were \$31.96 ( $\mathrm{SD}=\$ 9.91)$. 55 percent of subjects in our experiment are African-American with the rest being Caucasian. Session sizes range from 12 to 20 and we always recruit multiples of two to allow for random pairings.

\section{Demand for Self-Revealing}

The main research question is whether subjects have a positive WTP to reveal their own characteristics. This would imply that players believe that they can use their own characteristics to influence the actions of others. Table 1 shows clear evidence of such behavior. Out of 51 subjects with the option to reveal (trustors in T1 and trustees in T2), 25 (49 percent) reveal their picture for at least one decision.

Table 1

\begin{tabular}{lllll}
\hline \hline & \multicolumn{2}{c}{ Trustor } & \multicolumn{2}{c}{ Trustee } \\
\cline { 2 - 5 } Price & \multirow{2}{*}{ Revealed } & $\begin{array}{l}\text { Not } \\
\text { Revealed }\end{array}$ & Revealed & Not Revealed \\
\hline$\$ 0.10$ & 13 & 16 & 11 & 11 \\
$\$ 1.00$ & 4 & 25 & 9 & 13 \\
\hline \hline
\end{tabular}

Notes: The table presents counts of how many subjects choose to reveal their own picture for the two prices, $\$ 0.10$ and \$1.00. We only include subjects who have the option to reveal (trustors in T1 and T2). Every subject faces both prices as each makes two decisions. 
Furthermore, we observe that subjects respond to prices as predicted by economic theory higher prices lead to a smaller number of subjects choosing to reveal ( $p$-value of 0.023). This implies downward-sloping demand for self-revelation. While 24 subjects (47 percent) reveal at a price of 10 cents, only 13 subjects (25.5 percent) decided to reveal at the higher price of $\$ 1$. This is coincidentally quite similar to Eckel and Petrie’s (2011) finding that 50 percent of subjects give up \$0.20 to reveal their partner’s identity, 22 percent are willing to pay \$1.

In terms of different behavior across the two roles (trustor and trustee), we find that trustees are more likely to reveal pictures ( $p$-value 0.093). Furthermore, trustees purchase more pictures, on average, if they have the option to do so (0.91 vs. 0.59 ; $p$-value $=0.049)$. Conditional on purchasing at least one picture, the same pattern emerges (1.67 vs. 1.31 ; $p$-value $=0.011)$. This translates into trustees paying more for self-revealing, on average, as prices are constant across treatments.

We estimate a linear probability model (LPM) for the probability of purchasing a picture with price, session fixed effects, and indicator variables for race and gender. Estimated coefficients indicate a negative impact of price (coefficient: -0.239 ; $p$-value $=0.03$ ) and the role of trustor is nearly significant at the $\mathrm{p}<.05$ level (coefficient: -0.289 ; $p$-value $=0.069$ ). Male subjects and black subjects seem to reveal their pictures slightly less but these effects are not significant at conventional levels. If we alter the model by including an interaction of role and price, we find that trustors are more price-sensitive at the $\mathrm{p}<.10$ level but not that the $\mathrm{p}<.05$ level (coefficient: -0.242; $p$-value $=0.087$ ).

Taken together, the evidence indicates that many (though not all) subjects place a strictly positive value on revealing their own picture in an economic transaction. In other words subjects - and especially trustees - seem to expect higher payoffs if they reveal themselves to the partner. In further research we will probe the mechanisms underlying this behavioral pattern.

\section{Behavior of Trustees and Trustors}

In the baseline experimental cell (C), subject behavior exhibits significant variance. Trustors send an average of 4.5 tokens across all groups, but both treatments reduce the average amount sent. These numbers are in the neighborhood of what other undergraduate students playing the trust game in other studies reveal (see, e.g., the 2011 meta-analysis due to Johnson and Mislin). Trustors in the control group send an average of 4.9 tokens, whereas trustors who can reveal their 
own photographs send an average of 4.53, and trustors whose partners can reveal send an average of 4.25 .

Yet, trustors who actually choose to reveal their own photographs or whose partners reveal their photographs do not send any more or less money. Demographic covariates strongly predict how much a trustor sends. In our sample, men are substantially more trusting than women (sending an average of 5.28 compared to 3.08 tokens).

This variation is not visible in trustees, who return an average of around 5.5 tokens across all demographic groups (note that trustees are shown a screen with 10 sliders, one for each amount that a trustor could potentially send. As such, these numbers represent an average). The regression analysis shows that when either partner reveals their photograph the trustee chooses to return more of what he or she is sent, with an effect size on the order of 1-2 tokens--see Table 2.

Table 2

\begin{tabular}{|c|c|c|c|}
\hline & (1) & (2) & (3) \\
\hline & $\begin{array}{l}\text { Trustor } \\
\text { Sent }\end{array}$ & $\begin{array}{l}\text { Trustor } \\
\text { Sent }\end{array}$ & $\begin{array}{l}\text { Trustor } \\
\text { Sent }\end{array}$ \\
\hline $\begin{array}{l}\text { Revealed own } \\
\text { photo }\end{array}$ & $\begin{array}{l}2.155^{* *} \\
(0.428)\end{array}$ & & \\
\hline Black & $\begin{array}{l}-1.305 \\
(0.921)\end{array}$ & $\begin{array}{l}-1.128 \\
(1.004)\end{array}$ & $\begin{array}{l}-1.207 \\
(0.914)\end{array}$ \\
\hline Male & $\begin{array}{l}- \\
1.019 * * * \\
(0.153)\end{array}$ & $\begin{array}{l}- \\
0.593^{* *} \\
(0.121)\end{array}$ & $\begin{array}{l}-1.035^{* * *} \\
(0.152)\end{array}$ \\
\hline $\begin{array}{l}\text { Partner } \\
\text { revealed photo }\end{array}$ & & $\begin{array}{l}0.910 * * \\
(0.237)\end{array}$ & \\
\hline $\begin{array}{l}\text { Black partner } \\
\text { revealed photo }\end{array}$ & & & $\begin{array}{l}2.456 \\
-1.957\end{array}$ \\
\hline Session FE & Yes & Yes & Yes \\
\hline Constant & $\begin{array}{l}7.811^{* * *} \\
(0.46)\end{array}$ & $\begin{array}{l}7.267 * * \\
* \\
(0.59)\end{array}$ & $\begin{array}{l}7.762 * * * \\
(0.457)\end{array}$ \\
\hline Observation & 136 & 136 & 136 \\
\hline
\end{tabular}

Notes: Standard error in parentheses.

${ }^{*} \mathrm{p}<0.05,{ }^{* *} \mathrm{p}<0.01,{ }^{* * *} \mathrm{p}<0.001$

Note also that trustees return 1-2 tokens more when their partner reveals that they are black (although this is not statistically significant), but that this effect is not observed in trustors. 


\section{Impact of Self-Revealing on Earnings}

Overall payoffs do not change substantially when partners reveal their picture. The one noticeable change in raw averages comes when trustees reveal to trustors - in that case trustees make less (average of 25.5 vs overall average of 28.3) and trustors make more (average of 16.3 vs 15.3). In a regression analysis, the signs of the relevant coefficients match this result, but the relevant coefficients are not statistically significant at conventional levels. Yet, one should note that these are preliminary results and samples are small. Firming up these results is one focus of future research, as is determining the nature and extent of why picture revelation works (see also List, 2004).

\section{Discussion}

Subjects are willing to pay to reveal information about themselves to their partners in a trust game. However, this is not necessarily the result of a rational belief that revealing information will enable greater trust. On the contrary, when it did anything detectable at all, revealing information appeared to function as a very inefficient transfer. Further research with larger samples will help determine whether revealing information in a laboratory game is indeed rationally self-interested, perhaps the function of altruism (as hinted at by trustees returning more tokens when they reveal their own photographs), or other factors.

\section{REFERENCES}

DeBruine, Lisa M. 2002. “Facial Resemblance Enhances Trust” Proceedings of the Royal Society of London B: Biological Sciences 269, no 1498: 1307-12.

Eckel, Catherine C., and Ragan Petrie. 2011. "Face Value." American Economic Review, 101(4): 1497-1513.

Edelman, Benjamin, Michael Luca and Daniel Svirsky. 2015. "Racial Discrimination in the Sharing Economy: Evidence from a Field Experiment." Unpublished manuscript, 30 pp: Harvard Business School.

Goldin, Claudia and Cecilia Rouse. 2000. "Orchestrating Impartiality: The Impact of Blind Auditions on Female Musicians." American Economic Review, 90(4): 715-741.

Hammermesh, Daniel S. and Jeff E. Biddle. 2001. "Beauty and the Labor Market." American 
Economic Review, 84(5): 1174-1184.

Johnson, Noel and Alesandra Mislin. 2011. Trust Games: A Meta-Analysis. Journal of Economic Psychology, 32: 865-889.

Landry, Craig, Andreas Lange, John A. List, Michael K. Price, and Nicholas G. Rupp. 2006. "Toward an Understanding of the Economics of Charity: Evidence from a Field Experiment," Quarterly Journal of Economics, 121(2): 747-782.

List, John A., 2004. "The Nature and Extent of Discrimination in the Marketplace: Evidence from the Field," Quarterly Journal of Economics 119(1): 49-89.

Oosterhof, Nikolaas N. and Alexander Todorov. 2009. "Shared Perceptual Basis of Emotional Expressions and Trustworthiness Impressions from Faces.” Emotion 9(1): 128-133.

Oreopoulos, Philip. 2011. "Why do Skilled Immigrants Struggle in the Labor Market? A Field Experiment with Thirteen Thousand Resumes." American Economic Journal: Economic Policy, 3(4): 148-171.

Pope, Devin G. and Justin R. Sydnor. 2011. "What's in a Picture? Evidence of Discrimination from Prosper.com." Journal of Human Resources, 46(1): 53-77.

Scharlemann, Jorn, Catherine C. Eckel, Alex Kacelnik and Rick K. Wilson. 2001. "The Value of a Smile: Game Theory with a Human Face”, Journal of Economic Psychology, 22: 617-40. 